\title{
Penggunaan Teknik Melukis Inkonvensional untuk Meningkatkan Kemampuan Kreativitas Anak Kelompok B di TKQ X (Penelitian Tindakan Kelas)
}

\author{
Hamidah Fadlilah*, Dedih Surana \\ Prodi Pendidikan Guru PAUD, Fakultas Tarbiyah dan Keguruan, Universitas \\ Islam Bandung, Indonesia. \\ *hamidahfadlilah5@gmail.com, dedihsurana@unisba.ac.id
}

\begin{abstract}
This class action research was carried out based on the problems that emerged in group B children in the Salam Manunggal Al-Qur'an Kindergarten, namely the undeveloped ability of children's creativity. Children have not been able to express their ideas in making a painting. Follow-up from these problems, the need for a learning that can stimulate children's creativity. Researchers design learning activities using unconventional painting techniques (close techniques) to enhance the creativity abilities of group B children using classroom action research methods. The purpose of this study include: to find out how the initial conditions of children's creativity ability before the action using unconventional techniques, knowing the process or stages of increasing children's creativity ability using unconventional painting techniques, and knowing the results of using unconventional painting techniques to enhance the creativity of group B children in the Kindergarten of the Qur'an Salam Manunggal. The subjects in this study were group B children of Salam Manunggal Al-Qur'an Kindergarten with a total of 10 children. The end result of children's creativity ability shows a significant increase after the application of unconventional painting techniques. This can be seen from the ability of children's creativity that has improved from the initial condition, in the pre-cycle $80 \%$ of children fall into the category of Not Developing (BB) and $20 \%$ of children belong to the category of Starting to Develop (MB). At the end of Cycle 1,70\% of children were in the Underdeveloped (BB) category and 30\% of children were in the Start Development (MB) category, at the end of Cycle 2, 40\% of children were in the Developing According to Expectation (BSH) category, 30\% of children were categorized as Starting Developing (MB), and 30\% of children are in the Underdeveloped (BB) category, at the end of cycle 3, $40 \%$ of children are in the Very Good Development (BSB) category, 30\% are in the Developmental Expectancy (BSH) category and 30\% of children are in the category of Start Developing (MB). Based on the results of this study, painting activities using unconventional painting techniques can be used as one of the learning methods that can be used to improve children's creativity.
\end{abstract}

Keywords: Creativity, painting, unconventional painting techniques.

\begin{abstract}
Abstrak. Penelitian tindakan kelas ini dilakukan berdasarkan permasalahan yang muncul pada anak kelompok B di TKQ Xyaitu belum berkembangnya kemampuan kreativitas anak. Anak belum mampu untuk menuangkan ide-idenya dalam membuat sebuah lukisan. Tindak lanjut dari permasalah tersebut, diperlukannya suatu pembelajaran yang dapat menstimulus kemampuan kreativitas anak. Peneliti merancang kegiatan pembelajaran menggunakan teknik melukis inkonvensional (teknik tutup) untuk meningkatkan kemampuan kreativitas anak kelompok B dengan menggunakan metode penelitian tindakan kelas. Tujuan dari penelitian ini antara lain: untuk mengetahui bagaimana kondisi awal kemampuan kreativitas anak sebelum dilakukkanya tindakan menggunakan teknik inkonvensional, mengetahui proses atau tahapantahapan peningkatan kemampuan kreativitas anak menggungakan teknik melukis inkonvensional, dan mengetahui hasil penggunaan teknik melukis inkonvensional untuk meningkatkan kreativitas anak kelompok B di TK-Q Salam Manunggal. Subjek dalam penelitian ini adalah anak kelompok B TKQ Xyang berjumlah 10 anak. Hasil akhir kemampuan kreativitas anak menunjukan peningkatan yang cukup segnifikan setelah diterapkannya teknik melukis inkonvensional. Hal ini dapat terlihat dari kemampaun kreativitas anak yang sudah meningkat dari kondisi awal, pada pra siklus $80 \%$ anak masuk kedalam kategori Belum Berkembang (BB) dan 20\% anak masuk kategori Mulai Berkembang (MB). Pada akhir siklus 1, 70\% anak masuk kategori Belum Berkembang (BB) dan 30\% anak masuk kategori Mulai Berkembang (MB), pada akhir siklus 2, 40\% anak masuk kategori Berkembang Sesuai Harapa (BSH), 30\% anak masuk kategori Mulai Berkembang (MB), dan 30\% anak masuk kategori Belum Berkembang (BB), pada akhir siklus 3, 40\% anak masuk kategori Berkembang Sangat Baik (BSB), 30\% masuk kategori Berkembang sesuai Harapan (BSH) dan 30\% anak masuk kategori Mulai Berkembang (MB). Berdasarkan hasil penelitian ini, kegiatan melukis menggunakan teknik melukis inkonvensional dapat digunakan sebagai salah satu metode pembelajaran yang dapat digunakan untuk meningkatkan kemampuan kreativitas anak.
\end{abstract}

Kata Kunci : Kreativitas, melukis, teknik melukis inkonvensional. 


\section{A. Pendahuluan}

Anak usia dini tengah tumbuh dan berkembang sesuai usianya. Ketika anak bertambah usia, maka bertambah pula pengalaman dan kemampuannya. Semakin banyak anak memperoleh pengalaman, maka akan tumbuh cabang sel-sel saraf yang akan meningkatkan potensi dan meningkatkan kesiapan anak menghadapi dunia luar. Untuk mengembangkan aspek perkembangan anak secara optimal, maka dibutuhkan proses yang berkesinambungan. Salah satu hal penting yang harus dikembangkan dari anak adalah kemampuan kreativitasnya. Anak usia dini masuk kedalam fase pra operasional. Anak yang berada pada fase pra operasional berpikir secara simbolik yang dihadirkan dalam berbagai bentuk fantasi, kemampuan ini merupakan pintu untuk meningkatkan kreativitas anak. Meningkatkan kreativitas anak adalah suata hal yang penting, anak yang perkembangan kreativitasnya baik akan berfikir secara divergen, sehingga akan memiliki beberapa alternatif pemecahan masalah untuk satu masalah saja.

Pengamatan lapangan yang telah peneliti lakukan pada kelompok B di TKQ Xuntuk melihat kemampuan kreativitas anak, mendapatkan simpulan bahwa anak-anak kelompok B di TKQ Xmasih kurang dalam segi kerativitasnya, 8 dari 10 anak di kelompok B terlihat kesulitan dalam berkreasi dengan karyanya, sebagian anak masih sangat membutuhkan bantuan untuk membuat karyanya. Hal ini disebabkan oleh beberapa faktor, diantaranya: kurangnya rangsanag atau stimulus dari guru, serta kurangnya media yang disedikan oleh pihak sekolah untuk menstimulus kemampuan kreativitas anak. Ada banyak upaya yang dapat dilakukan untuk meningkatkan kemampuan kreativitas anak, salah satunya menggunakan Teknik melukis inkonvensional yaitu teknik tutup. Tujuan penelitian ini dari permasalahan yang ada antara lain untuk mengetahui:

1. Kemampuan Kreativitas anak kelompok B sebelum penggunaan teknik melukis inkonvensional di TKQ Salam Manunggal.

2. Proses atau tahapan-tahapan peningkatan kemampuan kreativitas anak pada kelompok B di TKQ Xdengan menggunakan Teknik inkonvensional.

3. Hasil penggunaan teknik melukis inkonvensional untuk meningkatkan kreativitas anak kelompok B di TKQ Salam Manunggal.

\section{B. Landasan Teori}

Supriadi (Rachmawati \& kurniati, 2017:13) mengutarakan bahwa kreativitas adalah kemampuan seseorang untuk melahirkan sesuatu yang baru, baik berupa gagasan, maupun karya nyata yang relatif berbeda dengan apa yang telah ada. Wahyudin (Mulyani, 2019:3) mengatakan bahwa kreativitas berarti kemampuan menghasilkan sesuatu yang baru dan orisinal yang terwujud ide-ide dan alat-alat, serta lebih spesifik lagi, keahlian untuk menemukan suatu yang baru. Setiap anak memiliki potensi kreativitas dalam dirinya, tentunya ia membutuhkan kegiatan yang penuh dengan ide-ide kreatif. Anak secara alamiah dianugrahi oleh Allah swt rasa ingin tahu, makai ia dapat mempelajari suatu hal dengan caranya sendiri. Mulyani (2019:24) memaparkan meskipun setiap anak memiliki potensi kreatif alamiah di dalam dirinya, tapi potensi tersebut tidak akan optimal jika tidak digali dan diasah sejak dini. Seperti halnya perkembangan dasar yang lain, kreativitas juga perlu diberi kesempatan, rangsangan, dan arahan dari keluarga dan lingkungan sosial (guru dan pihak sekolah) untuk berkembang.

Melukis menurut Pamadhi dan Evan (2009:3.20) adalah membayangkan, mengaitkan, mengasosiasikan, mengimajinasikan baik benda yang ingin dilukis ada di depan mata atau pun tidak. Salah satu manfaat dari melukis adalah memunculkan ide-ide kreatif pada anak. Dapat disimpulkan bawaha kegiatan melukis dapat digunakan untuk oleh guru untuk memunculkan ide-ide kreatif anak yang ada dalam pikirannya kedalam sebuah karya dan dapat meningkatkan kemampuan kreativitas anak. Dalam melukis tentunya dibutuhkan teknik, salah satu teknik dalam melukis adalah teknik inkonvensional

Teknik Inkonvesioanl menurut pamadhi (2009:3.35) merupakan cara berkreasi menggunakan peralatan dan teknik yang tak biasa. Cara kerjanya seperti eksperimen 
(percobaan). Teknik melukis terbagi menjadi beberapa bagian, salah satunya adalah teknik tutup. Phamdi dan evan (2009:3.35) memaparkan teknik tutup merupakan teknik campuran antara teknik basah dengan teknik kering. Teknik basah karena menggunakan media cat air. Sedangkan dikatakan teknik kering karena media lain yang akan digunakan adalah media pastel (krayon). Teknik tutup ini juga dapat diartikan menutup sebagian gambar dengan berbagai macam bahan dan kemudian diselesaikan dengan pewarnaan

Tabel 1. Alat-alat yang digunakan dalam Teknik Tutup

\begin{tabular}{|l|l|l|}
\hline \multicolumn{1}{|c|}{$\begin{array}{c}\text { Alat dan } \\
\text { bahan }\end{array}$} & \multicolumn{1}{|c|}{ Jumlah } & \multicolumn{1}{c|}{ Keterangan } \\
\hline Cat asturo & $\begin{array}{l}3 \text { warna dasar dan warna } \\
\text { puti }\end{array}$ & $\begin{array}{l}\text { Untuk memberi } \\
\text { warna pada kertas }\end{array}$ \\
\hline Kertas karton & 1 karton & Dibuat bentuk A4 \\
\hline Spon & 1 spon besar & $\begin{array}{l}\text { Di potong bentuk } \\
\text { kotak digunakan } \\
\text { untuk } \\
\text { mengaplikasikan cat }\end{array}$ \\
\hline $\begin{array}{l}\text { Piring } \\
\text { pelastik }\end{array}$ & 5 piring atau lebih & $\begin{array}{l}\text { Digunakan untuk } \\
\text { menampuk cat }\end{array}$ \\
\hline Air & Secukupnya & $\begin{array}{l}\text { Dapat digunkan jika } \\
\text { cat terlalu kental }\end{array}$ \\
\hline
\end{tabular}

Langkah-langkah melukis dengan teknik tutup, Antara lain: 1) Gambar pola gambar terlebih dahulu; 2) Potong pola yang sudah di gambar tadi; 3) kemudian ditempelkan pada kertas atau media lukis yang akan digunakan; 4) Jika sudah tertutup, maka bisa mulai memberi warna dengan mengelilingi pola gambar menggunakan spon; 5) Warnai mengelilingi pola hingga selesai; 6) Buka pola yang ditempel tadi; 7) akan terlihat hasil cetakan tadi; 8) Berikan cat warna pada bagian-bagian yang belum diwarnai.

\section{Hasil dan Pembahasan}

Hasil dari penelitian berdasarkan metode penelitian tindakan kelas dengan judul "Penggunaan Teknik Melukis Inkovensional Untuk Meningkatkan Kemampuan Kreativitas Anak Kelompok B Di TKQ Salam Manunggal".

Penelitian ini dilakukan pada 10 anak kelompok B di TKQ Salam Manunggal, terdiri dari 3 siklus dengan tema tanaman. Alat yang digunkan untuk menilai kemampuan kreativitas anak adalah lembar observasi. Berikut merupakan hasil peningkatan pada pra siklus, akhir siklus 1, akhir siklus 2, dan akhir siklus 3 yang dapat dilihat pada diagram berikut:

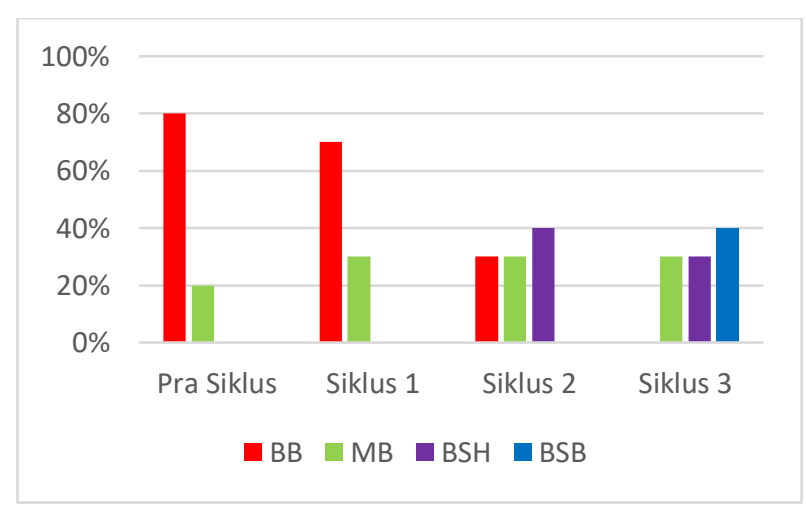

Gambar 1. Diagram Siklus 
Berdasarkan pada hasil diagram diatas dapat terlihat ada peningkatan secara bertahap yang terjadi pada setiap siklus. Pada pra sikus, $80 \%$ anak masuk kategori Belum Berkembang dan 20\% anak masuk kategori Mulai berkembang. Pada akhir siklus 1, $70 \%$ anak masuk kategori Belum Berkembang (BB) dan 30\% anak masuk dalam ketegori Mulai Berkembang (MB). Pada akhir siklus 2 kemampuan kreativitas anak menjadi $40 \%$ anak masuk pada kategori Berkembang Sesuai Harapan (BSH), 30\% anak masuk pada kategori Mulai Berkembang (MB), dan 30\% anak masuk dalam kategori Belum Berkembang (BB). Pada akhir siklus 3 kemampuan kreativitas anak menjadi $40 \%$ anak masuk kedalam kategori Berkembang Sangat Baik (BSB), 30\% anak masuk kedalam Ketegori Berkembang Sesuai Harapan (BSH), dan 30\% anak masuk kedalam kategori Mulai Berkembang (MB)

Berdasarkan penjabaran diatas dengan adanya peningkatan kemampuan kerativitas anak pada setiap siklus, dapat disimpulkan bahwa kegiatan melukis dengan menggunakan teknik melukis inkonvensional (teknik tutup) dapat digunakan sebagai salah satu kegiatan pembelajaran yang berguna untuk meningkatkan kemampuan kreativitas anak.

\section{Kesimpulan}

Berdasarkan pada hasil penelitian tentang meningkatkan kreativitas anak melalui kegiatan melukis menggunakan taknik tutup pada anak kelompok B di TKQ Salam Manunggal, dapat disimpulkan sebagai berikut:

1. Berdasarkan pengamatan awal, kemampuan kreativitas anak dalam menuangkan ideidenya untuk membuat sebuah lukisan sebelum dilakukannya tindakan masih dalam kategori kurang, dapat dilihat dari 80\% anak masuk kategori Belum Berkembang (BB) dan $20 \%$ anak masuk Kategori Mulai Berkembang (MB).

2. Pelaksannan pembelajaran dalam meningkatkan kemampuan kreativitas anak dengan menggunkan teknik tutup pada kelompok B di TKQ Salam Manungal dilakukan dalam 3 siklus, dengan menggunkana tema tanaman.

3. Kegiatan melukis dengan menggunakan teknik tutup mengalami peningkatan pada setiap siklusnya. Sebab kemampuan kreativitas anak lebih baik dari pada pra siklus. Pada Akhir siklus 1, 70\% anak masuk kategori Belum Berkembang (BB) dan 30\% anak masuk kategori Mulai Berkembang (MB). Pada Akhir siklus 2, 40\% anak masuk kategori Berkembang Sesuai Harapan (BSH), 30\% anak masuk kategori Mulai Berkembang (MB), dan 30\% anak masuk Kategori Belum Berkembang (BB). Pada Akhir siklus 3, $40 \%$ anak masuk kategori Bekembang sangat baik (BSB), 30\% anak masuk kategori Berkembang sesuai harapan (BSH), dan 30\% anak masuk kategori Mulai Berkembang (MB). Dapat disimpulkan bahwa kegiatan melukis menggunakan teknik tutup dapat menjadi salah satu cara yang diggunakan untuk meningkatkan kemampuan kretivitas anak.

\section{Daftar Pustaka}

[1] Arikunto, S dkk. (2016). Penelitian Tindakan Kelas. Jakarta: PT Bumi Aksara

[2] Martono. (2017). Pembelajaran Seni Lukis Anak Untuk Mengembangkan Imajinasi, Ekspresi, dan Apersiasi (online). Prosiding Seminar Nasional Pendidikan FKIP UNTIRTA 2017 (7 januari 2020)

[3] Masganti, S dkk. (2016). Pengembangan Kreativitas Anak Usia Dini (teori dan trik) (online). Medan: Perdana Publishing (19 Mei 2019)

[4] Masnipal. (2018). Menjadi Guru PAUD Profesional. Bandung: Rosda

[5] Mulyani, N. (2019). Meningkatkan Kreativitas Anak Usia Dini. Bandung: Rosda

[6] Munandar, U. (2014). Pengembangan kreativitas. Jakarta: Rineka Cipta

[7] Muslich, Masnur. (2012). Melaksanakan PTK (Penelitian Tindakan Kelas). Jakarta: PT Bumi Aksara

[8] Pamadhi, H. dan S.S., Evan. (2009). Seni Keterampilan Anak. Jakarta: Universitas Terbuka

[9] Paizaluddin \& Ermalinda. (2013). Penelitian Tindakan Kelas (Classroom Action Researsh): 
Panduan Teoritis Dan Praktis. Bandung: ALFABETA

[10] Rachmawati, Y \& Euis Kurniati. (2017). Strategi Pengembangan Kreativitas anak: Usia Taman kanak-kanak. Jakarta: Kencana 